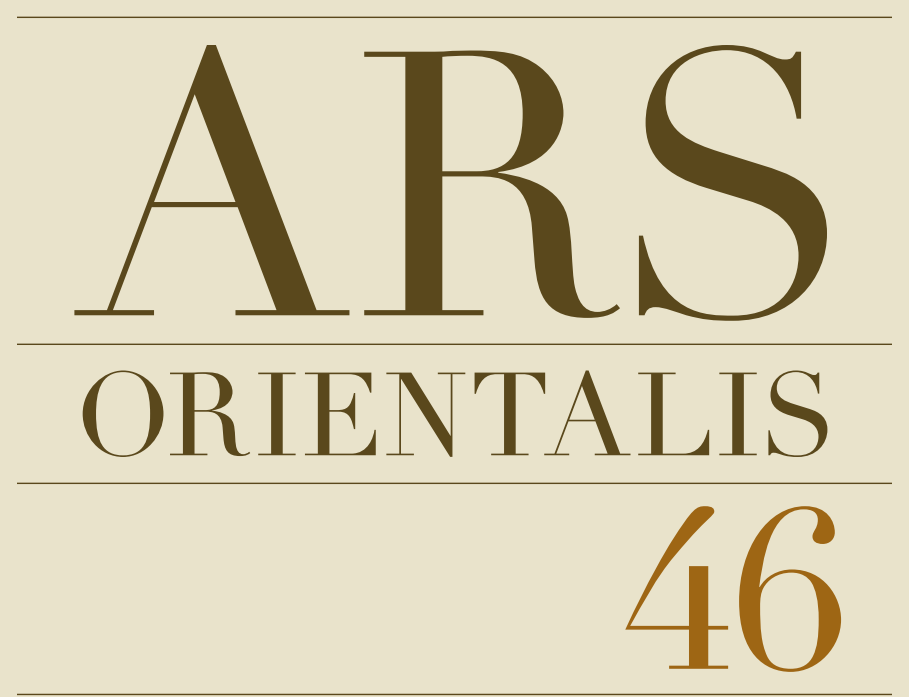


ARS ORIENTALIS 46

EDITOR-IN-CHIEF

Nancy Micklewright

ADVISORY BOARD

Nachiket Chanchani

Louise Cort

Marian Feldman

Jennifer Robertson

Jan Stuart

Melanie Trede

EDITOR

Jane Lusaka

Joelle Seligson

MANAGING EDITOR

Zeynep Simavi

DESIGNER

Edna Jamandre

EDITORIAL OFFICES

Ars Orientalis

Freer Gallery of Art

Smithsonian Institution

P.O. Box 37012, MRC 707

Washington, DC 20013-7012

For deliveries

(DHL, FedEx, UPS, courier):

1050 Independence Avenue, SW

Washington, DC 20560
ISSN 0571-1371

Printed in the United States of America

(C) 2016 Smithsonian Institution,

Washington, D.C.

Ars Orientalis is a peer-reviewed annual volume of scholarly articles on the art and archaeology of Asia, the ancient Near East, and the Islamic world. It is published jointly by the Freer and Sackler Galleries and the University of Michigan Department of History of Art. Fostering a broad range of topics and approaches through themed issues, the journal is intended for scholars in diverse fields. Ars Orientalis provides a forum for new scholarship, with a particular interest in work that redefines and crosses boundaries, both spatial and temporal. Authors are asked to follow The Chicago Manual of Style, 16th edition.

Ars Orientalis is now available online at arsorientalis.si.edu.

Ars Orientalis subscriptions are handled by Turpin Distribution. (For contact information, go to www.asia.si.edu/research/ArsOrientalis.asp.)

Current subscription rates (including shipping):

$\begin{array}{llll}\text { U.S. individual } & \text { U.S. institution } & \text { International individual } & \text { International institution } \\ \text { Print: } \$ 48 & \text { Print: } \$ 58 & \text { Print: } \$ 55 & \text { Print: } \$ 68 \\ \text { Online: } \$ 40 & \text { Online: } \$ 48 & \text { Online: } \$ 40 & \text { Online: } \$ 48 \\ \text { Bundle: } \$ 55 & \text { Bundle: } \$ 65 & \text { Bundle: } \$ 60 & \text { Bundle: } \$ 80\end{array}$

Subscription-related inquires (invoice, payment, and change of address): turpinna@turpin-distribution.com (Canada, Mexico, USA) custserv@turpin-distribution.com (all other countries)

The full text of Ars Orientalis is also available in the electronic versions of Art Index and online through JSTOR (www.jstor.org). Beginning with volume 42 (2012), it is also indexed and abstracted in the Art and Humanities Citation Index. 


\section{CONTENTS}

7 INTRODUCTION

Michelle C. Wang and Wei-cheng Lin, guest editors

13 EARLY CHINESE BUDDHIST SCULPTURES AS ANIMATE BODIES AND LIVING PRESENCES

Michelle C. Wang

40

BETWEEN THE LIVING AND THE DEAD

Three-Tail Funeral Banners of Northern Thailand

Rebecca S. Hall

61 ASCENDING TO A BUDDHA LAND

A Study of a Pagoda Valley Sculpture on Namsan in Unified Silla

Sunkyung Kim

100 PERFORMING CENTER IN A VERTICAL RISE

Multilevel Pagodas in China's Middle Period

Wei-cheng Lin

136 INSTANT BLISS

Enactment of the Miraculous Appearance of Relics in the Hōryüji Nested

Reliquary Set

Akiko Walley

173 PERFORMING MIND, WRITING MEDITATION

Dōgen's Fukanzazengi as Zen Calligraphy

Charlotte Eubanks

198 FACELESS GAZES, SILENT TEXTS

Images of Devotees and Practices of Vision in Medieval South Asia Jinah Kim 


\title{
EARLY CHINESE BUDDHIST SCULPTURES AS ANIMATE BODIES AND LIVING PRESENCES
}

\begin{abstract}
Miracle tales from medieval China recorded the ability of Buddhist statues to walk, speak, emit light, and even feel pain. Consecration ceremonies, however, emphasized the sense of vision and the agency of the ritual practitioner over the agency of the statue. This essay argues that by underscoring the corporeal agency of animated sculptures, which was manifested both in their extraordinary qualities and in their vulnerability to damage, the circulation of miracle tales enabled a participatory practice in which devotees, monks and laypeople alike, were able to engage in the performative act of writing statues into life.
\end{abstract}

\section{Introduction}

A comparison of image consecration rituals and medieval Chinese literary accounts of Buddhist sculptures reveals an intriguing contradiction between the agency of the sculptures and the agency of devotees. On the one hand, Buddhist clergy and devotees acted upon the sculptures, empowering and investing them with a spiritual presence through the performance of elaborate, eye-opening ceremonies. On the other hand, Chinese miracle tales omitted references to consecration ceremonies but frequently described Buddhist sculptures as animate bodies-statues that moved at will, emitted light, and even spoke. How can such seemingly contradictory perspectives be reconciled with one another? This essay argues that miracle tales regarding animate sculptures are crucial for assessing how Chinese devotees understood, at a visceral level, the transformation of inert materials into a living presence. Miracle tales operated performatively by emphasizing the somatic agency of Buddhist sculptures rather than the sense of sight, which was accentuated in image consecration ceremonies. ${ }^{1}$

In his book What Do Pictures Want?, W. J. T. Mitchell poses the following question: "Why do [people] behave as if pictures were alive, as if works of art had minds of their own, as if images had a power to influence human beings, demanding things from us, persuading, seducing, and leading us astray?"2 If we substitute "sculpture" for "picture," we might ask similar questions regarding the status of early Buddhist sculptures in China. This essay takes as a starting point the notion that if statues were considered to be alive, they must have had their own prerogatives, desires, and needs - what, then, were they? In turn, what did their needs and desires reveal about those of devotees?

The supernatural phenomena recorded in miracle tales are generally attributed to ganying 感应, defined as the sympathetic response of Buddhist deities to the reverential actions of devotees. Without denying the resonance of this sympathetic response to the worldview of miracle tales-or the role that those tales played in 


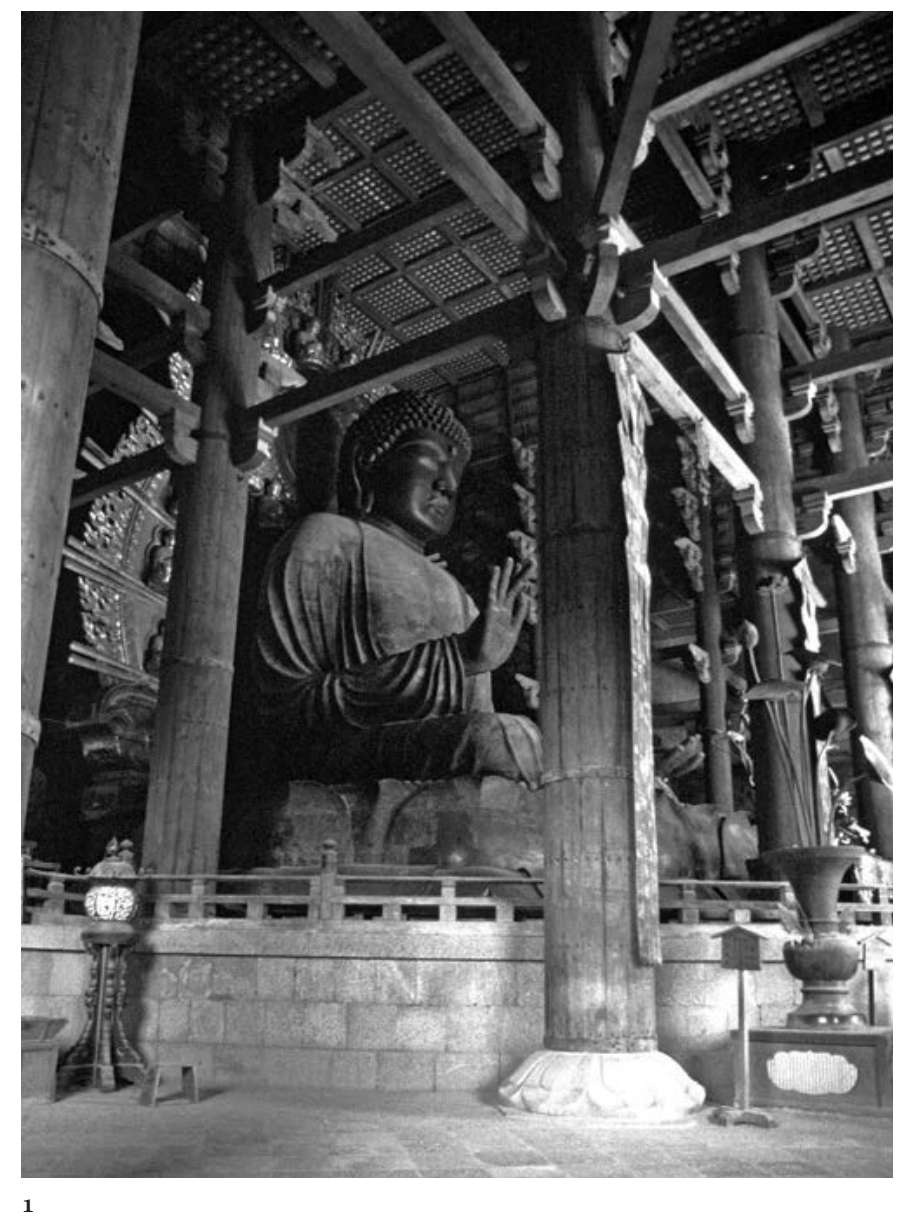

1

Great Buddha of Tōdaiji. Nara, Japan. Mid-Nara period (710-94), restored in the 12 th and 17 th centuries. Bronze, $15 \mathrm{~m}$ (h). Photograph by John C. Huntington, courtesy of the Huntington Photographic Archive at the Ohio State University reinforcing concepts of divine intervention or karmic retribution-I argue that we should take literary accounts of animated sculptures at their word. As reflected in miracle tales, the perceived agency of sculptures is crucial to understanding how they were imagined to fulfill their roles as Buddhist icons. My aim is not to offer a purely clerical or lay perspective that is grounded in consecration rituals or miracle tales, but rather to focus on sculptures as active agents in medieval Chinese Buddhism and examine what that perceived agency reveals about the motivations of human devotees.

\section{Image Consecration Rituals and the Appeal to Vision}

Buddhist image consecration or eye-opening (kaiguang 开光) rituals are ceremonies that mark the final stage in the production of a sculpted or painted icon, after which it is considered a sacred and animated work. Depending upon how an image is made, the consecration may involve painting in the sculpture's pupils, pricking the eyes with a pin, or anointing the eyes with a liquid such as oil. ${ }^{3}$ The emphasis, therefore, is on sight. According to the logic of the consecration ceremony, endowing the inert materials of clay, bronze, stone, or wood with the sense of sight brings a sculptural icon to life. The insentient quality of the statue at the center of the consecration ritual may be described as "not unlike a dead body that [has been] brought to life."

Perhaps the most famous such account in Buddhist history concerns the eyeopening ceremony of the Great Buddha in Tōdaiji 东大寺(Nara, Japan) in 752 (fig. 1). 


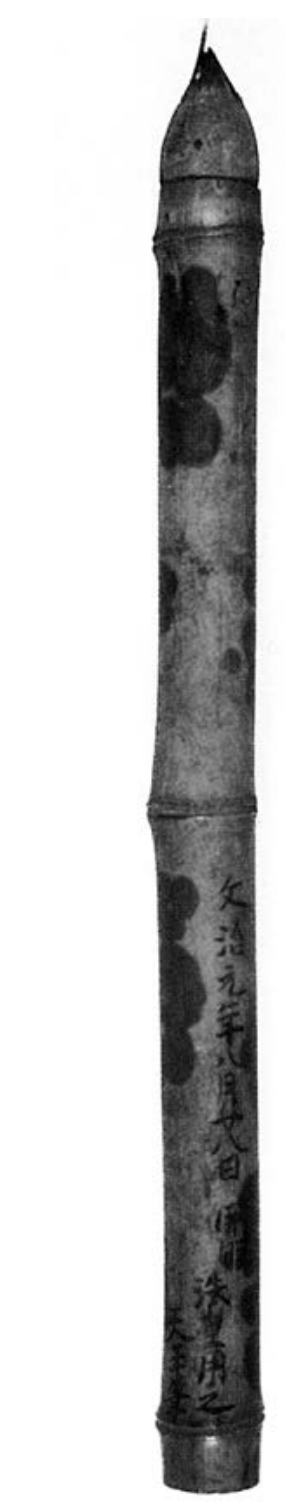

2

Paintbrush used during the Tōdaiji eye-opening ceremonies. Shōsō-in, Tōdaiji, Nara, Japan. $56.6 \times 4.3 \mathrm{~cm}$. After Nara Kokuritsu Hakubutsukan 奈良国立博物館, ed., Shōsōin ten: rokujukkai no ayumi 正倉院展: 六十 回のあゆみ (Nara: Nara Kokuritsu Hakubutsukan; Kyoto: Hatsubai Shibunkaku Shuppan, 2008), 40

3

Blue silk cords used during the Tōdaiji eye-opening ceremonies, Shōsō-in, Tōdaiji, Nara, Japan. After Nara Kokuritsu Hakubutsukan 奈 良国立博物館, ed., Shōsōin ten: rokujukkai no ayumi 正倉院展: 六十 回のあゆみ (Nara: Nara Kokuritsu Hakubutsukan; Kyoto: Hatsubai Shibunkaku Shuppan, 2008), 149

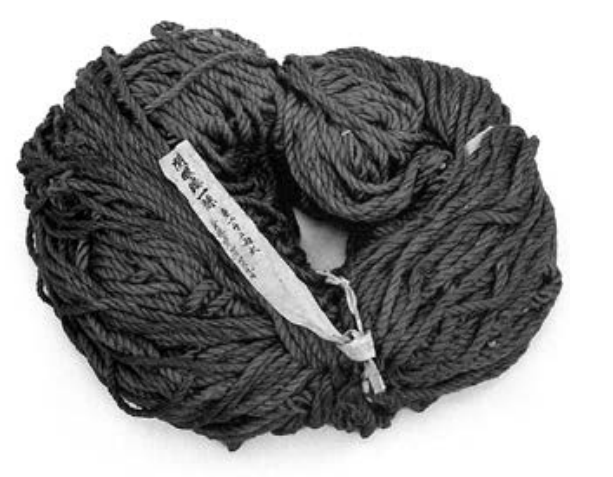

3

This monumental sculpture, now sixteen meters tall after several periods of restoration, was installed in the Great Buddha Hall of Tōdaiji, the main temple of the national system of Buddhist monasteries. Seated atop an elaborate lotus pedestal, the Buddha represents Vairocana Buddha of the Avatamsaka Sütra. The consecration ceremony of the Great Buddha was led by the South Indian monk Bodhisena (704-760) and attended by Emperor Shōmu 聖武天皇 and Empress Kōmyō 光明 皇后. In all, more than ten thousand monks participated. The ceremony began with the entrance of the emperor, empress, court officials, and a smaller number of monks into the temple grounds and Great Buddha Hall. A giant paintbrush (fig. 2) was affixed to cords (fig. 3) measuring more than two hundred meters long, so that while Bodhisena stood on a ladder to paint in the eyes of the colossal sculpture, those standing on the ground could hold onto the cords and help wield the paintbrush. ${ }^{5}$ After the eyes of the Buddha had been painted, a reading and sermon on the Avatamsaka Sütra, in which Vairocana Buddha plays a central role, were delivered and the remaining monks entered the temple grounds. ${ }^{6}$

At this point, the four main temples of Kyoto presented offerings, and musicians and dancers were escorted onto the grounds. Several types of musical and dance performances then unfolded in sequence, from those associated with the Japanese court and aristocratic clans to those originating from foreign nations, including China and regions of Central and Southeast Asia. The performances entailed the wearing of costumes and elaborate masks, the playing of musical instruments, and the use of theatrical props. ${ }^{7}$

The consecration ritual described above incorporated aspects of performancemusic and dance-that were enacted before an audience of clergy, court officials, and the imperial couple. The performance, however, can be distinguished from the performative and participatory actions of painting in the Buddha's eyes and the teaching of the Avatamsaka Sütra. The painting of the eyes was more than the completion of the sculpture. Rather, it was a beginning, as this act bestowed the sacred presence upon the sculpture and brought it to life. The sütra teaching likewise contributed to the sacrality of the sculpture by situating it within its doctrinal context. Importantly, these performative actions involved not only Bodhisena but the participation of other attendees as well, thus blurring the line between performer and audience in a way that differed from the passive appreciation of music and dancing that followed the painting in of the Buddha's eyes. ${ }^{8}$

Just as the consecration ceremony privileged the agency of the ritualist who led the ceremony as well as the sense of sight, it also emphasized the dormant materiality of the statue and acknowledged its potential to come to life. Medieval Chinese 
miracle tales, however, made no note of eye-opening ceremonies in their descriptions of sculptures as animate bodies. This was despite the contemporaneous evidence for eye-opening ceremonies in dedicatory inscriptions. ${ }^{9}$ Rather, miracle tales observed the ability of statues to emit radiant light, move, stand still, sweat, and speak - that is, touching on nearly all the senses except sight. It was sight that enabled devotees to recognize the divine nature of statues, and it could serve as the raison dêtre for the production of statues because it allowed people to gaze upon the Buddha although he was absent. Most anecdotal accounts of the miraculous discovery of sculptures remarked upon their discovery or first sighting. Sight, however, does not seem to have been considered evidence of the sculptures' lifelike qualities; that is, their ability to see or, more specifically, what they saw was generally not remarked upon. If we as readers are aware of the devotee's gaze on the statue, we are rarely cognizant of the gaze the statue returns to the devotee. ${ }^{10}$

The first statue ever created of the Buddha fulfilled the desire of an Indian monarch to gaze upon the Buddha in his absence. Different stories regarding this image exist in various textual sources, although the general parameters of the tale remain consistent. According to Pāli sources, King Pasenadi of Kosala went to the Jetavana Monastery to visit the Buddha, only to find him away. When the Buddha returned the next day, the king remarked upon his disappointment at the Buddha's absence and stated his wish to have an image of the Buddha made. The Buddha agreed, promising great merit to anyone who would do so. A sculpture correctly displaying the thirty-two marks of the Buddha's body was accordingly made of sandalwood, decorated with gold, and dressed in yellow robes. ${ }^{11}$ The king invited the Buddha to view the sculpture. As the Buddha entered the shrine in which the sculpture had been installed, the statue rose to greet him in a gesture of recognition. ${ }^{12}$

In other versions of the tale, such as those found in medieval China, King Udayana of Kauśāmbì commissioned the sculpture of the Buddha, who had spent the summer retreat preaching to his deceased mother Māyā in Trāyastriṃśa heaven. Distraught at the Buddha's absence, the king dispatched a piece of sandalwood along with thirty-two skilled artisans to heaven to observe the Buddha and carve his thirty-two marks. Similar to the ending in Pāli versions of the tale, the statue rose to greet the Buddha in a gesture of recognition. ${ }^{13}$ In yet another version, The Sütra on the Ocean-Like Samädhi of the Visualization of the Buddha (T643, Foshuo guan Fo sanmeihai jing 佛說觀佛三昧海經), translated into Chinese by Buddhabhadra between 398 and 421, King Udayana commissioned a sculpture of the Buddha in gold, which walked in the air to greet the Buddha. ${ }^{14}$

In a dialogue between King Udayana and the Buddha in the Sütra on the Production of Buddha Images (T692, Foshuo zuo Foxingxiang jing 佛說作佛形像經), the importance of vision is underscored. The king states: 
In the heavens above and on earth below there are none who compare to the Buddha. The face, eyes, and body of the Buddha now shine forth magnificently, and I never weary for a moment of gazing upon the Buddha. The Buddha is presently the teacher of all those in the heavens above and the earth below, and many are those who revere the Buddha's compassion.

Further in the dialogue the king states, "I dread no longer being able to look upon the Buddha after the Buddha is gone."15

What we can glean from these accounts is, first of all, the importance of vision on the part of King Udayana (or King Pasenadi) and the corresponding emphasis placed upon the statue's expressions of corporeality. The impetus for the creation of the statue is that the king might be able to gaze upon the Buddha in his absence. The statue, in turn, expresses its recognition of its originating source, the Buddha, by standing up to greet him. It is not content merely to be the passive recipient of the devotee's gaze. Vision must have been involved, as we assume that the statue recognized the Buddha by sight, and the Buddha was invited by the king to view his effigy. But in this instance, vision served as a gateway for confirmation of the statue's likeness and corporeality, which was expressed through its gesture of rising to greet the Buddha.

Furthermore, it is in the interaction between the sculpture and the Buddha that it is validated as having been made in the Buddha's image. ${ }^{16}$ The movement of the statue, then, may even be understood to have constituted a consecratory act in and of itself, comparable to the eye-opening ceremony discussed earlier. Regarding the eye-opening ceremonies of contemporary Thailand, Donald Swearer notes that the interaction between monks who are associated with the perfections of the Buddha and the image at the center of the consecration ceremony "validates the images being consecrated as the Buddha's double."17 This sentiment is echoed by Peter Stewart in his work on Roman statues, in which he observes, "Physical contact with statues seems to activate the illusion of life in the lifeless artefact." ${ }^{18}$ The interaction between the sculpture and others, whether the Buddha himself or eminent monks, is therefore key to the endowment and recognition of its sacredness. While the interaction may initially be prompted by vision, it is cemented through the sculpture's expression of corporeality and agency.

\section{Miracle Tales and Sympathetic Response}

Literary accounts of animated Buddhist sculptures appear in collections of Buddhist miracle tales, which flourished from the late Eastern Jin 东晋 (317-420) to the Tang 唐 (618-907) dynasty. ${ }^{19}$ These tales focused on strange and supernatural accounts concerning Buddhist clergy, devotees, and related events, drawing 
upon an earlier Chinese tradition of zhiguai 志怪 literature or anomaly accounts. ${ }^{20}$ Miracle tales were also closely related to the writing of Buddhist hagiographies. ${ }^{21}$ Although miracle tales generally were composed by laypeople and took laypeople as protagonists, they were collated nonetheless in a wide variety of Buddhist literature. Two prominent examples are the encyclopedia Fayuan zhulin 法苑朱琳 (T2122, Pearl Garden of the Dharma Forest), compiled by the monk Daoshi 道世 (fl. 7th century) by around 661, ${ }^{22}$ and Ji shenzhou sanbao gantong $l u$ 集神州三宝感 同录 (T2106, Record of the Miraculous Responses of the Three Treasures in China), compiled by the monk Daoxuan 道宣 (596-667) in 664. ${ }^{23}$ For this reason, it is difficult to assume that miracle tales embraced a purely lay outlook, as opposed to the clerical perspective reflected in consecration ceremonies. It is more productive to consider the division of labor between the two, as well as how they contributed to a holistic view of the empowerment and animation of Buddhist sculptures and devotees' recognition of them as empowered icons.

The indigenous concept of ganying has its roots in pre-Buddhist Chinese cosmological thought of the late Zhou 周 (1046-256 вCE) to early Han 汉 (206 вCE$220 \mathrm{CE}$ ) dynasty. Gan means "to affect," and ying means "to respond." Accordingly, ganying may be defined as an apparently spontaneous response stimulated by certain actions in a "universe conceived holistically in terms of pattern and interdependent order." ${ }^{24}$ In classical Chinese views of statesmanship, the moral failings of a ruler, for example, could be reflected in any number of strange omens, including natural phenomena such as earthquakes and the appearance of fantastical animals. ${ }^{25}$ In the Buddhist context, ganying refers to the mechanism by which repeated acts of profound devotion motivate a timely and appropriate response from a Buddha or bodhisattva. ${ }^{26}$ In this light, the concept of ganying has conventionally been viewed as an instrument for the sinicization of Buddhism and the translation of Buddhist concepts of merit-making, divine intervention, and karmic retribution into layman's terms. ${ }^{27}$

An example of how the concept of ganying operated in Buddhist miracle tales is demonstrated in the following story, which centers on the bodhisattva Avalokiteśvara (Chinese: Guanyin 观音). The Lotus Sütra and efficacy of devotion to Avalokiteśvara figured prominently in the early development of Buddhist miracle tales. ${ }^{28}$ The preface from the Mingxiangji 冥祥记 (Signs from the Unseen Realm) by Wang Yan 王琰 (circa 454-circa after 502) narrates the author's ardent devotion to a small icon of Avalokiteśvara that he had been given as a child. The sculpture was known to emit light and appear in Wang's dreams as a portent. Then Wang was separated from the sculpture for ten years. Fearing that his connection with the statue was permanently severed, Wang nevertheless continued to search for it. In his dreams one night, a man appeared and revealed the statue's current location, 
whereupon devotee and icon were reunited. It was in fact the divine responses that Wang experienced and his knowledge of similar cases that encouraged him to compile Mingxiangji. ${ }^{29}$

In this tale, the miraculous response of the statue is clearly attributed to the devotion of Wang Yan, whose reverence to it had been constant since childhood. He made offerings to the statue and was concerned about its whereabouts; his devotion, in turn, triggered the statue's emission of light and its appearance in his dreams. Another reason offered by Wang for the miraculous response of the statue was its resemblance to the bodily marks of the deity. The efficacy of the substitute is subsequently confirmed through the sculpture's emission of light and animation:

The sutras say that whatever is molded, carved, drawn, or sketched, if it matches in kind the marks on the body [of the divine personage being represented], can move and emit light. In the recent two cases of Saakyamuni and Maitreya in the Western regions that gave off light and functioned like the beings they represent, they must surely have possessed the correct marks. ${ }^{30}$

In a similar tale, spiritual response (shenying 神應) plays an instrumental role in the mysterious circumstances of a statue's creation. According to the Fayuan zhulin, Dai Yong 戴颙 was commissioned to make a sculpture of Avalokiteśvara for a certain Jiang Yi 江夷of Qiyang 濟陽 in modern-day Jiangsu province.

[Dai Yong] expended his physical and mental energy in his wish to create something utterly beautiful. However, the bodily marks wouldn't come out right, so for many years the statue remained unfinished. Then in a dream, someone told him that Jiang Yi had no karmic affinity with Avalokiteśvara and that the statue should be changed to one of Maitreya bodhisattva. Dai promptly stopped his work and quickly wrote a letter to Jiang. His letter had not yet been sent when Jiang's letter arrived. He had had the same dream that night, down to the very words. Dai took delight in the spiritual response (shenying 神應) and changed the statue to Maitreya. Thereupon, whatever he touched turned out marvelous. He did not pause to reflect until the luminous countenance was complete in its full perfection. With eulogies of praise, everyone recognized the unerring nature of predestination (yinyuan 因缘). ${ }^{31}$ 
Both of these tales focus on the karmic bond between a deity and devotee as the stimulus for the response from the unseen world. The patron Jiang Yi presumably desired a sculpture of Avalokiteśvara, for he commissioned it from Dai Yong. His intentions were nonetheless thwarted by the eventual realization that his karmic relationship was not with Avalokiteśvara, but rather Maitreya. This is conveyed through the spiritual response of the dream, an intervention that revealed the predestination of the karmic bond between Jiang Yi and Maitreya as well as the lack of agency on the part of both patron and sculpture. The narrative pays acute attention to the supernatural elements of the tale. These, in turn, are made legible on the body of the sculpture, its marks, and its state of existence or nonexistence. The sculpture, then, becomes a site of negotiation, making tangible the unseen realm of spiritual response and predestination. ${ }^{32}$ As Wang Yan stated, "Here, too, in recent years there have been many cases of responses to people's stimuli in which, by the conduits of mere wood and stone, anomalies from the unseen world have appeared." ${ }^{33}$

In both tales, icons not only function as vessels for the unseen, but they also appear to assume a somewhat passive role. In the Wang Yan story, the Avalokiteśvara icon emitted light and appeared in his dream. However, when it was in real danger of becoming permanently separated from Wang, a mysterious man appeared in Wang's dream and revealed the statue's location. Likewise, in the case of Dai Yong and Jiang $\mathrm{Yi}$, an unidentified person appeared in their dreams to explain why the sculpture should be changed. In neither case did the statue communicate directly with the patron or sculptor or behave in such a way to provoke a response from a human bystander. One might say that although the statues were clearly acknowledged and revered as sacred icons, they did not act in a way that suggested their full range of animation and autonomy.

Yet another miracle tale focusing on Avalokiteśvara introduces a different perspective on the agency of the image. As recorded in the Guang yi ji 廣异记 (Great Book of Marvels), compiled by Daifu 戴孚 in the third quarter of the eighth century, a monk named Daoxian 道憲 was entrusted with the task of having seven images of Avalokiteśvara painted for the prefect Yuan 元. As he oversaw the cutting of timber for a temple hall, he fell into a fast-moving river. His only resource was to fix his mind upon Avalokiteśvara, after which:

... in the watery depths he saw a strange light. He gazed at this for a long while, and perceived that the seven bodhisattvas he had painted were standing beside him. They said to Daoxian: "Just reverently call on the bodhisattva." Daoxian [was walking] as if in broad daylight, but was still aware that he was under water and feared he would surely die. Then he thought of a 
plan - to call upon Amitābha Buddha. So he did then call upon that Buddha.

The seven bodhisattvas together supported his feet and conducted him to the surface. ${ }^{34}$

This tale represents a marked departure from the previous two. The paintings of the seven bodhisattvas now speak directly to Daoxian, compelling him to call upon Avalokiteśvara for assistance. In this manner, the images unmistakably assert their own presence upon the human bystander by initiating contact. The rapport between image and devotee extends to physical touch, as the images support Daoxian's feet, thus bringing him to safety. The conventional view might simply assert that the paintings were expedient forms of the deity, rather than paintings come to life. ${ }^{35}$ But as Glen Dudbridge has noted, there are examples of miracle tales in which the images themselves are clearly at work. ${ }^{36}$ Furthermore, these tales deemphasize the role of the consecration ceremony in sacralizing Buddhist sculptures.

One instance of this is another tale from the Guang yi ji, which pertains to the wife of Zhou Zhezhi 周哲滞 (née Xi 席). When she fell ill, she commissioned the casting of two Buddha sculptures as an offering for her health. However, she died before the sculptures were completed. The story proceeds:

To begin with a crowd of demons seized Xi and took her up a mountain. But suddenly they heard two people call out from behind, telling them to pause for a moment. The demons drew back and dared not stir. When the two arrived, their complexions were dirty black and their faces covered over with dust and soil. They struck fear in the demons, who all scattered in terror. And they then led Xi back to her home, where she heard her family and household weeping and wailing. The two took her right up in front of the dead body and ordered her to enter it. She then came back to life. Those two people were the two freshly cast Buddhas. ${ }^{37}$

Importantly, not only were the statues in the tale above unconsecrated, they also were unfinished. They are described in the tale as having darkened faces, suggesting that they had freshly emerged from the mold and were not yet polished. Their empowerment was not attributed to the agency of ritual specialists but rather to the urgency of their own imperative to save their patron. Dudbridge characterizes the statues as inhabiting "a different universe from the ritual manuals studied by Strickmann." 38 One might even question whether the consecration ceremony introduces the deity into an inanimate object or whether it simply awakens a force within an object that is already considered sacred. ${ }^{39}$ Perhaps 
even more evident than in the tale of Daoxian, Xi's Buddha sculptures act not as vessels for the Buddha or another numinous presence, but rather of their own agency; the sculptures themselves are at work in this tale. ${ }^{40}$ They are the ones who approach Xi and lead her back to her home and body. Previously, a comparison was made between the insentient state of an unconsecrated Buddha statue and a dead body. This tale, in effect, turns the logic of the eye-opening ceremony completely upside down: the unconsecrated statues consecrate, or bring to life, the dead body of $\mathrm{Xi}$, rather than the other way around. The roles of statue and devotee are hereby reversed.

\section{The Sculpted Body in Motion}

We turn now to a close analysis of selected miracle tales that address two somewhat contradictory themes regarding the agency of animated Buddhist sculptures: the sculptures' supernatural or wondrous qualities versus their vulnerable or human qualities. In these case studies, sculptures exercised full use of their bodies and acted in ways that prompted a response from devotees. Sculptures acted to prevent their own destruction, and they were able to walk, speak, and even feel pain. In short, their actions appeared not simply as uncomplicated manifestations of ganying but rather as expressions of the corporeality of the sculpted body. Their animation confirmed that they possessed fully functional bodies, and it was in these acts of animation that their sacredness was recognized by devotees. ${ }^{41}$ What was the role of the senses in expressing the corporeal agency of sculptures, and what role, if any, was played by vision, which was emphasized in the eye-opening ceremony?

To begin with, a sixth-century tale from Luoyang qielan ji 洛陽伽監記 (T2092, The Monasteries of Luoyang, authored by Yang Xuanzhi 楊街之 in 547) records the story of a district magistrate named Duan Hui 段暉. On the grounds of his mansion,

the sound of a ringing bell was frequently heard underground, and from time to time, a five-colored light could be seen shining upon the halls. Hui thought it strange and therefore excavated the location of the light, discovering one gilt sculpture, three chi 尺 high, with two bodhisattvas. On the pedestal there was an inscription reading "Jin, second year of Taishi 太始 (266), fifteenth day of the fifth month, made by the Daizhong zhongshujian Xun Xu 侍中中書監荀勗." Hui subsequently gave up his home so it could be turned into the temple Guangmingsi 光明寺. People at that time all said that this was the former location of Xun Xu's residence. Sometime later, a thief tried to steal this statue. The statue and bodhisattvas all shouted "Thief!" The thief was so frightened that he fainted. The monks who heard the sound of the statue's cry were able to successfully capture the thief. ${ }^{42}$ 
From this anecdote, we may arrive at several conclusions regarding the role of the senses as they relate to the animated statue. First, the presence of the statue was announced by sound and, most important, by sight, as it was located at the very location where the five-colored radiance appeared. Sight was therefore critical for its timely discovery. Through the reading of its dedicatory inscription, the statue's provenance was also established by sight. However, the statue's instincts of self-preservation, expressing its desire to stay in the temple that had been built in its honor, were expressed aurally through its cry. Its attachment to that location stretched back, in fact, to the third century, when it had been the residence of Xun Xu. Distinct from the dreams of Wang Yan, Dai Yong, and Jiang Yi, who were addressed by unknown people, this statue cried out directly, prompting the monks to catch the thief.

In other tales, statues demonstrated their capabilities of locomotion and either willingly left the boundaries of their site or participated in the act of ritual circumambulation. The abbot Dao An 道安 of Tanxi Temple 檀溪寺 in Xiangyang 襄陽, modern-day Hubei province, sponsored the production of a famous gilt bronze statue of Amitābha Buddha, which was completed in 375 CE. ${ }^{43}$

Each night, the statue emitted a light that thoroughly illuminated the buildings of the monastery. It also walked by itself to Wan Shan 萬山. The villagers went to gaze and worship it, and afterward, they returned it to the monastery. ${ }^{44}$

After the statue left the temple gates for the second time, the monastery's name was changed to the Golden Image Temple (Jinxiangsi 金像寺). Accounts about this statue comment upon the surprise of townspeople at its ability to walk. It is unclear whether it was witnessed in motion. Nevertheless, the statue left its footprint on a rock as definitive proof of its journeys. ${ }^{45}$ In another account, the origins of the Golden Image Temple are attributed to Amitābha having visited this site and built the temple. ${ }^{46}$

The story of the walking Amitābha statue begins in a similar fashion to the tale of Duan Hui's statue: it emits a bright light that shines upon the monastery's halls. However, while Duan Hui's statue exhibited a deep attachment to its home, the Amitābha statue walked alone to Wan Shan, giving villagers the experience of worshipping a statue firsthand. Nevertheless, the villagers knew the statue's proper location, as they returned it to the Golden Image Temple. Processions in which Buddhist icons and relics were taken outside of temples and paraded through crowds of spectators on Buddhist holidays were known in medieval China. ${ }^{47}$ In this case, however, the procession of the walking Amitābha statue was entirely self-determined. 
The walking Amitābha statue recalls the tale of Prince Jinghao 景皓 of Chenliu 陳留. Known for his magnanimity since childhood and for his good deeds, he ceded half of his palace in the western suburbs to the Buddhist establishment. ${ }^{48}$ The courtier Meng Zhonghui 孟仲睴 commissioned a statue for the prince, described as follows:

Its bodily marks possessed a majesty rarely seen in the world. It was placed in the prince's front chamber where it momentarily occupied a treasure throne. In the second year of Yongan 永安 [529], the sculpture walked around its throne each night. On all four sides its footprints were impressed upon the ground. Thereupon, scholars and commoners alike marveled at this, and everyone came to see. As a result, those whose hearts were stirred were incalculable. In the autumn of the third year of Yongxi 永熙 [534], [the statue] suddenly left of its own accord, and no one knew its whereabouts. ${ }^{49}$

In both examples, the statue's mobility not only allowed it to present itself to the gaze of a wider group of Buddhist devotees, thereby increasing its potency as an icon, but it was also a cause for marvel. The circumambulation of the walking statue of Prince Jinghao, however, raises more complex questions than the Amitābha statue of the Golden Image Temple. While the Amitābha statue merely walked from one place to another, Prince Jinghao's statue was actively engaged in what looked very much like a human act of worship. Was its intention to model appropriate religious behavior for human devotees? Was the statue worshipping itself? Or does the tale draw a fine line between the profane nature of the sculpture, which was merely an empty vessel, and the divinity hidden within?

Both statues left permanent traces of their peregrinations in the form of footprints. This detail is important, as their movements might otherwise have been hidden from the eyes of human bystanders. The footprints, in turn, were in themselves treated as a locus for worship. However, when the statue of Prince Jinghao suddenly disappeared in the year 534, it apparently left no such traces behind. One obvious drawback of walking statues was that with minds and wills of their own, they could suddenly disappear at a moment's notice.

Based upon the following tale, it is possible that the locomotion of statues was never fully intended to be witnessed by human eyes, an idea that perhaps enabled devotees to imagine that any sculpture had the potential to exhibit a similar agency. A metal statue was discovered in the year 347 to the north of Jingzhou City 荊州 城 and subsequently became well-known for its animation as well as its ability to portend events. In the second year of the Yongyuan 永元 era of the Qi 齊 (500), the statue's movements were accidentally witnessed by a bystander: 
$\ldots$ at the time when the prince of Nankang 南康王 [Xiao] Baorong [萧] 寶融 raised a rebellion, the statue walked out of the hall and was about to descend the stairs. Two monks saw it and gave out a cry of surprise, whereupon the statue turned around and went back in the hall. In the third year [501], Yingzhou 穎胄 died suddenly. Baorong was ousted and power returned to the Liang 梁 founder. ${ }^{50}$

In another tale pertaining to the same statue, dating to the end of the Tianjian 天鑒 era (502-19) of the Liang 梁 dynasty:

The temple's abbot Daoyu 道获 and a layperson were sweeping the grass alongside the pagoda. They opened the pagoda's doors and saw the statue circumambulating the shrine. Yu worshipped it secretly and didn't allow a word to be said. When the hall was formally opened, the statue was again on its pedestal. ${ }^{51}$

In the first account, the statue's movements were unexpectedly witnessed by two monks as it was about to leave its abode, causing it to turn around abruptly and return to its proper place. The cry of surprise emitted by the monks mirrors the shout of "thief!" uttered by Duan Hui's statue and evokes a similar sense of astonishment. When the same statue engaged in circumambulation in the second account, it continued its motions despite the presence of human bystanders, although it returned to its pedestal in time for the formal opening of the hall. In this instance, the movements of the statue were deemed worthy of secrecy, as Daoyu warned others against speaking of the phenomenon.

Certain statues, in fact, were deemed particularly capable of movement when hidden from the eyes of human bystanders. ${ }^{52}$ The moving sculptures of Liangzhou 凉州 were installed by Juqu Mengxun 沮渠蒙遜 (368-433), king of the Northern Liang, in the cliffs one hundred $l i$ 里 south of the city:

... some in stone and some in clay, there were countless variations so that worshippers were dazzled in mind and eye. Among them were clay holy monks who seem like men who must continually walk around because from the beginning, they had no place of repose. Seen from afar, they move; seen up close, they stop. Even their facial expressions have the appearance of movement. Sometimes, dirt has been spread on the ground in order to observe their movements. If others are far away, then they will tread on the ground and leave footprints, coming and going without end. The phenomenon has 


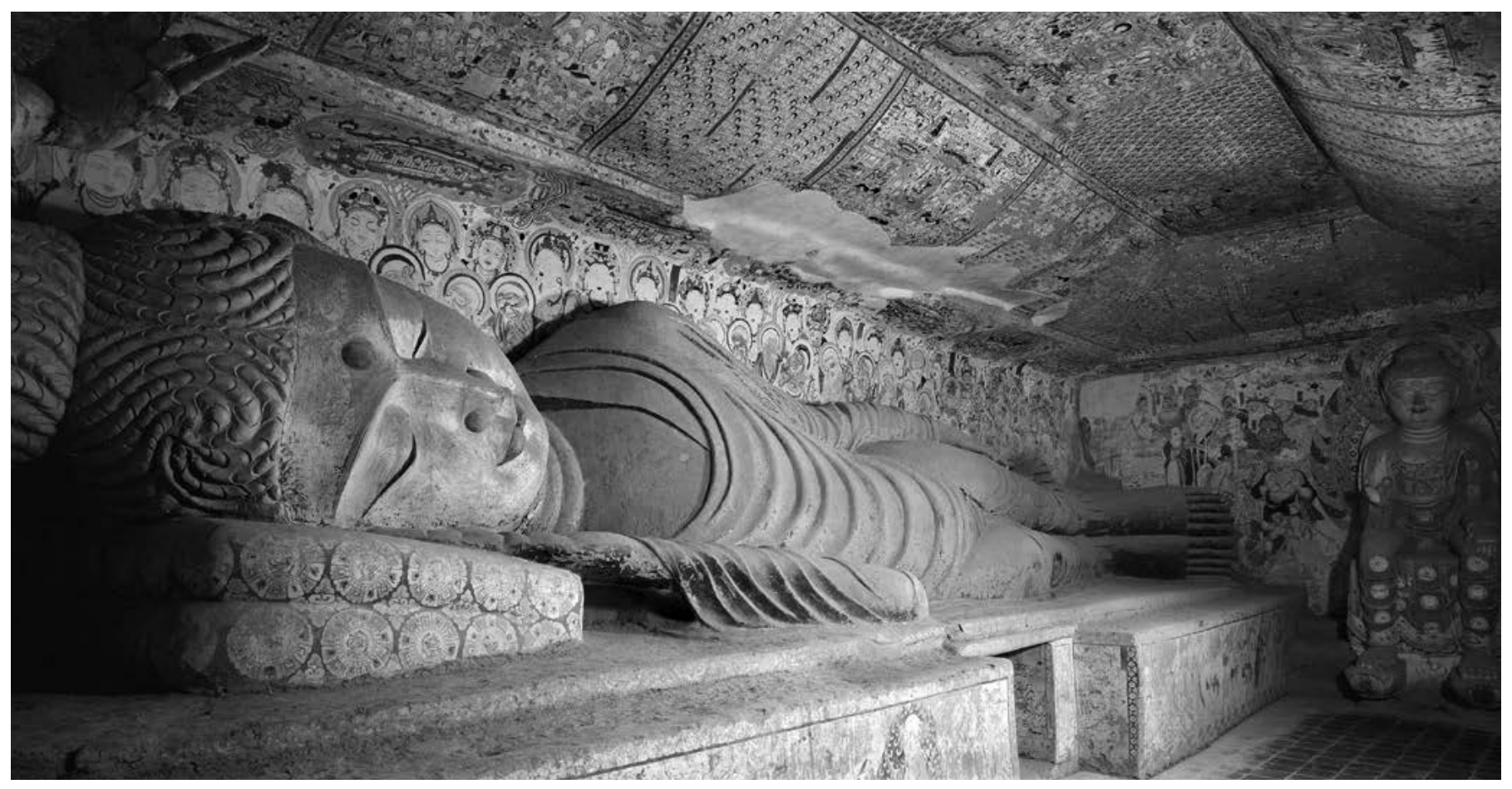

4

4

Parinirvāna Buddha, Mogao Cave 158 , Dunhuang, China, 8th-9th century, Tang dynasty (618-907). Photograph courtesy of the Dunhuang Academy continued like this for over a hundred years until the present-day, according to what others say. ${ }^{53}$

This tale is similar to those about the golden Amitābha statue and Prince Chenliu's statue in that dirt was spread on the ground in order to capture the elusive movements of the statues. However, this tale makes clear that these sculptures, from the description possibly representing Buddhist disciples known as luohan 罗 汉, moved only when out of the sight of human bystanders. Above all, this underscores the agency of sculptures and the sense that sculptures had lives of their own, parallel to human existence. Their movements were relegated to the margins of the day-to-day life of humans-after nightfall, before the temple opening, and other idle moments when humans were most likely to be caught off guard. The animation of sculptures was not a response to prayer or other devotional acts, but rather had the result of moving the hearts and minds of devotees. In such a manner, the secrecy attached to the animation of sculptures worked in a very different way from the logic of ganying, which endeavored to make visible the mysterious workings of the unseen realm. Walking statues, however, were rarely observed in motion, and the clearest evidence of their movement lay in the footprints that were captured in stone or pressed into dirt.

What was gained by imagining that statues possessed lives of their own and that the lives they possessed were hidden from the eyes of devotees? It is admittedly a bit difficult to read a living presence onto the material forms of Chinese Buddhist sculptures, particularly icons of the Buddha, which were rarely shown in motion. To do so would seem to require real effort, as Buddhist icons generally were marked by the stillness of their seated or standing positions. Indeed, parinirvāna images showed the Buddha lying on his side as if "sleeping"54 (fig. 4). It is curious that the prevailing thought in miracle tales is that statues were alive, since due to their still- 
ness, they easily could have been viewed as lifeless forms ${ }^{55}$ Consider the response of the viewers in these tales; perhaps one reason Buddhist devotees imagined the icons they worshipped to be animated forms was due to the sense of marvel those sculptures subsequently evoked. By imagining the statues' unseen locomotion, Buddhist devotees acknowledged the limitations of vision, even though vision was at the center of consecration ceremonies. The agency of statues not only was embodied in their qualities of animation but, as we will explore in the next section, it also was registered in the vulnerability of their bodies to injury and harm.

\section{Vulnerability and Materiality}

In a second group of miracle tales, statues act decisively in self-preservation, thus shifting the focus from their sacred or wondrous nature to their materiality and susceptibility to destruction, as well as their dependence upon human intervention. For example, in the Fayuan zhulin, two gilt silver statues originally commissioned under the founder of the Liang dynasty (502-77) were under order to be demolished and melted down for their metal by Du Kan 杜龕, the son-in-law of the grand marshal Wang Sengbian 太尉王僧辯.

He ordered several dozen men to climb the Sanxiu Pavilion 三休閣 and saw off the Buddha's uṣniṣas. They had just begun hammering and chiseling when the two statues at once turned around to glare at them. Thereupon, all of them felt as if their arms were about to fall off and could not be raised, and they were struck dumb as if completely drunk, including Du Kan. After some time, they regained consciousness; then they were afflicted by swelling bruises all over their bodies. All they could see were vajra guardians bearing fearsome weapons charging to attack them. They cried out in pain and felt as if their bodies were being roasted through. Pus and blood oozed through their skin and exposed their bones, whereupon they died. ${ }^{56}$

Several elements in this tale are noteworthy. First, the statues moved in full sight of their attackers, unlike earlier examples in which statues moved only when not in view. Furthermore, as the statues became more animated, the men lost control over their bodies, their arms and voices having been thoroughly incapacitated. Although the statues could see the men clearly, the men could see nothing but fearsome guardian deities rushing to attack them. The destruction that the men sought to perpetrate upon the statues' bodies was repaid in kind by physical harm to their own bodies and their eventual deaths. Statues in medieval China were often in danger of being melted down for cash. ${ }^{57}$ Here, the punishment seems particularly fitting, as the flesh of the men was literally roasted off their bones. 
In the Jianyuan 建元 era (479-82) of the Southern Qi dynasty, a stone sculpture originally from Funan 扶南國 (Cambodia) that was kept at the Vaiśāli Monastery 毘耶離精舍 in Panyu County 番禺, in modern-day Guangdong, was in danger from a fast-spreading fire:

Its appearance was extremely unusual. Seven, eight, or even ten men were required to hoist it aloft. One day, the monastery's thatched roofs caught on fire, reaching down to the rooms below. The smoke and flames enveloped the statue. A group of nuns, ten strong, looked at the statue in concern but had no idea what to do. Three or four of them tried to lift it, whereupon it floated in the air and out of danger. In the past, there wasn't a stone as heavy as thirty jin 斤 until this statue appeared. The monastery's rooms subsequently burned down. ${ }^{58}$

In this passage, the enumeration of the men required to lift the stone sculpture foregrounds its heaviness. This, in turn, serves as a foil to the statue's miraculous ability to spontaneously float up and away from danger's reach. Although human bystanders attempted to save the statue, they were unable to do so. Therefore, the statue's escape from the fire demonstrates a decisive response under duress. It was as susceptible to being "burned alive" as the human inhabitants of the monastery. The final sentence underscores the sense of urgency and the timeliness of the statue's dramatic act of self-preservation.

The Jingzhou metal statue discussed earlier also appears in the following episode, set in the Taiyuan 太元 era (376-95) during the reign of Emperor Xiaowu 孝武:

In the middle of the night, the statue exited the west gate of the monastery. The watchman thought it was a man and questioned the statue. When it failed to answer, he struck it with his sword and heard the clang of metal. Only then did he inspect it and realize that it was a statue. The sword strike left its mark on the statue's breast. ${ }^{59}$

This tale points not only to the vulnerability of the sculpted body, but also to its similarity to or interchangeability with the human body. The tales of Wang Yan, Dai Yong, and Jiang Yi all emphasized the correspondence between the bodily marks of a statue and those of a deity. This metal statue, on the other hand, was initially mistaken for a human by the night watchman, who attacked it with a sword. Although the watchman was near enough to the statue to strike it, and therefore must have been able to view it at close range, only when he heard metal clanging upon metal 
did he realize it was a statue. In this case, the sense of vision is less reliable than the sense of hearing. The sword subsequently left its mark on the statue, just as it would have wounded an ordinary human body.

The following two tales relate stories about statues that were injured and that subsequently appealed to devotees for assistance. The first concerns a gilt statue that was discovered during the Eastern Jin dynasty (317-420) by a daughter of Zhou Ji 周己, the governor of Wuxing 吳興. Zhou Ji’s family members, especially his daughter, were ardent followers of Buddhism. One day, a servant boy from his household went fishing, saw a bright light flowing toward him, and captured a gilded statue in his net. Only Zhou's daughter was able to retrieve it successfully from the water, and the statue was taken to the family home and worshipped.

At night, she dreamt that the Buddha's left knee was in pain. When she awoke, she saw that the statue's knee had a hole, so she cut off a length from a gold hairpin and patched it. ${ }^{60}$

In the second tale, a stone image was commissioned by the monk Senghu 僧護 of Lingshisi 靈石寺 in Jinzho 晉州 at the end of the Northern Qi dynasty (550-77). The statue was burned in a fire caused by the destruction of temples by Zhou troops in the territory.

In the beginning, it didn't change color and only two fingers were harmed.... Subsequently, it appeared in the dreams of a believer and said, "My injured fingers are in pain." That person understood and repaired them. ${ }^{61}$

In both tales, the human vocabulary of discomfort and physical malady is used to convey the predicament of the statues. They are not described as damaged but rather as injured and in pain. To relieve their suffering, they communicate directly with devotees in their dreams, prompting their timely restoration. Furthermore, the tales waver between the sentient quality of the statues and their inherent materiality as icons made of metal and stone. Although the statues describe themselves as being in pain, the repairs or patches, and therefore the ailments, are merely skindeep.

The previous section described the secret life of walking statues, icons that behaved in a manner that elicited wonder and surprise from devotees. In this section, we encounter statues that expressed the vulnerability of their bodies to various dangers, which made them seem more human. The Jingzhou sculpture, for instance, was even thought to be a man as it exited the monastery gate. At the same time, such tales highlighted the materiality or perhaps even artificiality of 


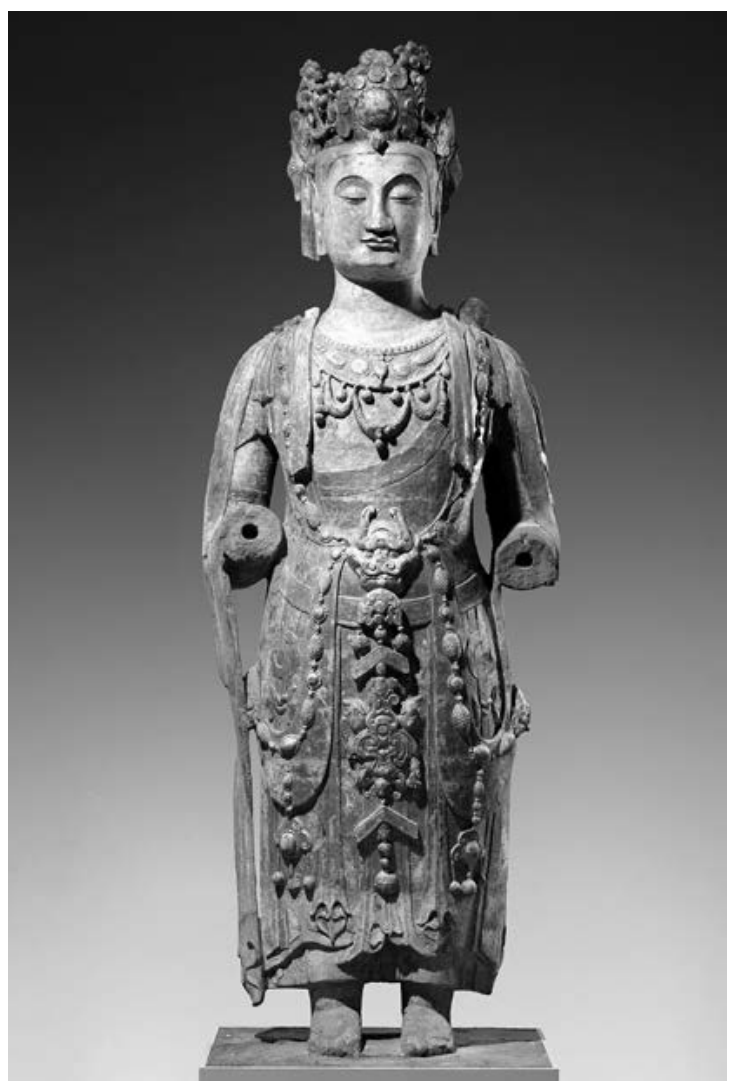

5

5

Bodhisattva, probably Avalokiteśvara (Guanyin). Shanxi province, China, ca. 550-50, Northern Qi dynasty (550-77). Sandstone with pigments, $419.1 \mathrm{~cm}$ (h). Metropolitan Museum of Art, Sackler Fund, 1965 (65.29.4). Image downloaded from www. metmuseum.org in accordance with the license-free Open Access for Scholarly Content (OASC) initiative. Work in the public domain
Buddhist statues by addressing their need to be repaired with like materials, such as the gold hairpin that Zhou's daughter used to fix the statue's damaged knee. Writing about statues in ancient Greece, Deborah Tarn Steiner draws a useful distinction between representations of deities that endowed them with fully human bodies, establishing "similarity-based relations," and those that instead depicted them in an archaic manner or with rigid bodily positions, raising questions about how close the gods could come to men "without suffering a loss of potency." 62 The statues in our case studies seem to occupy an intermediate position, displaying the marks and attributes of deities as well as of humans. As Robert Campany notes, statues did not serve merely as objects of devotion; they also were viewed as "companions." 63

The construction of Buddhist statues may even be interpreted as echoing, perhaps unintentionally, the organic construction of human bodies and their subsequent potential for movement. For example, clay or dry lacquer sculptures closely approximate the architecture of the human body. The modeled clay may be viewed as analogous to flesh, and in the case of dry lacquer sculpture, several layers of lacquer-soaked cloth are applied to the surface of the clay, functioning as an epidermis, albeit one that approximates not only skin but also hair, garments, and ornamentation. ${ }^{64}$ Likewise, the gilded outer layer of bronze sculptures might be understood as resembling skin, which is susceptible to sword or other damage. Statues may be described as emerging from bronze in the same way that organisms materialize from matter. ${ }^{65}$ Further contributing to the likeness between the sculpted body and human body, certain statues contained deposits consisting of textile simulacra of human organs. ${ }^{66}$ 


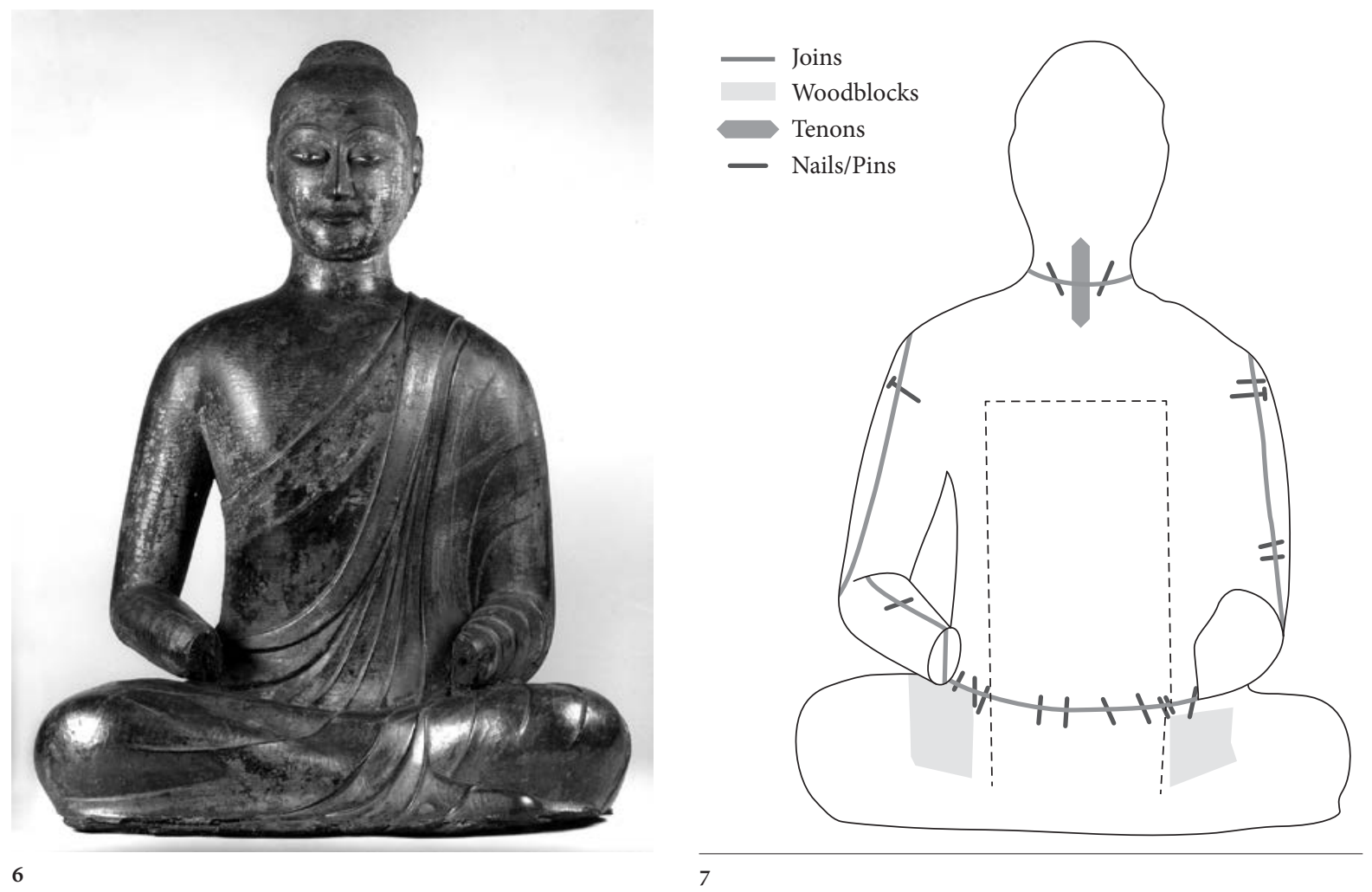

6

Buddha. China, ca. 590, Sui dynasty (581-618). Wood with painted lacquer, $105.1 \times 73.1 \times 55.1 \mathrm{~cm}$. Walters Art Museum (25.9). Photograph courtesy of the Walters Art Museum, used according to the Creative Commons Zero license. Work in the public domain

\section{7}

Drawing of Walters Art Museum's wood-core lacquer Buddha, with individual wood pieces, loose tenons, and nails delineated. From Leidy, Denise Patry, and Donna Strahan. Wisdom Embodied: Chinese Buddhist and Daoist Sculpture in The Metropolitan Museum of Art. Copyright (C) 2010 by the Metropolitan Museum of Art, New York. Reprinted by permission
The hands of premodern sculptures, in addition to peripheral elements such as headdresses and scarves, were often produced separately and connected to the main body of the sculpture by mortise and tenon joints or dowels. In some cases, the heads of sculptures may have been carved separately as well. ${ }^{67}$ For example, a Northern Qi stone bodhisattva in the Metropolitan Museum of Art was carved from a single block of sandstone, and the forearms, hands, and scarves, all of which extended away from the body and exceeded the depth of the original block of stone, were carved from separate pieces and joined to the body by dowels (fig. 5). ${ }^{68} \mathrm{~A}$ drylacquer seated Buddha sculpture in the Walters Art Museum was produced in three separate parts: head, torso, and knees. Loose tenon joints and iron nails were used to attach the head and knees to the torso (figs. 6-7). ${ }^{69}$ In all of these examples, the joints of the sculpted body coincide with the joints of the human body and seem to anticipate the potential for movement that was articulated in miracle tales, i.e., the ability of statues to turn their heads, walk, and touch devotees. Moreover, the tendency to carve sculptural elements separately becomes more obvious in statues that display a greater sense of movement, such as a wooden sculpture of Avalokiteśvara (figs. 8-9) that was carved from three separate blocks for the main figure and smaller blocks for peripheral elements, such as the hands and feet. The separate pieces were attached to the body with loose tenons and dowels. ${ }^{70}$

In miracle tales, the movements and utterances of Buddhist sculptures not only demonstrate their roles as passive objects of worship or vehicles of anomalies from the unseen world, but also the real agency that they possess as animated bodies. By considering their somatic existence, we look at Buddhist sculptures in ways that account for the conceptualization of sculptures as living presences capable of imposing their own sensibilities upon those around them. Furthermore, the agency of Buddhist sculptures was apparent not within ritual spaces or contexts but 


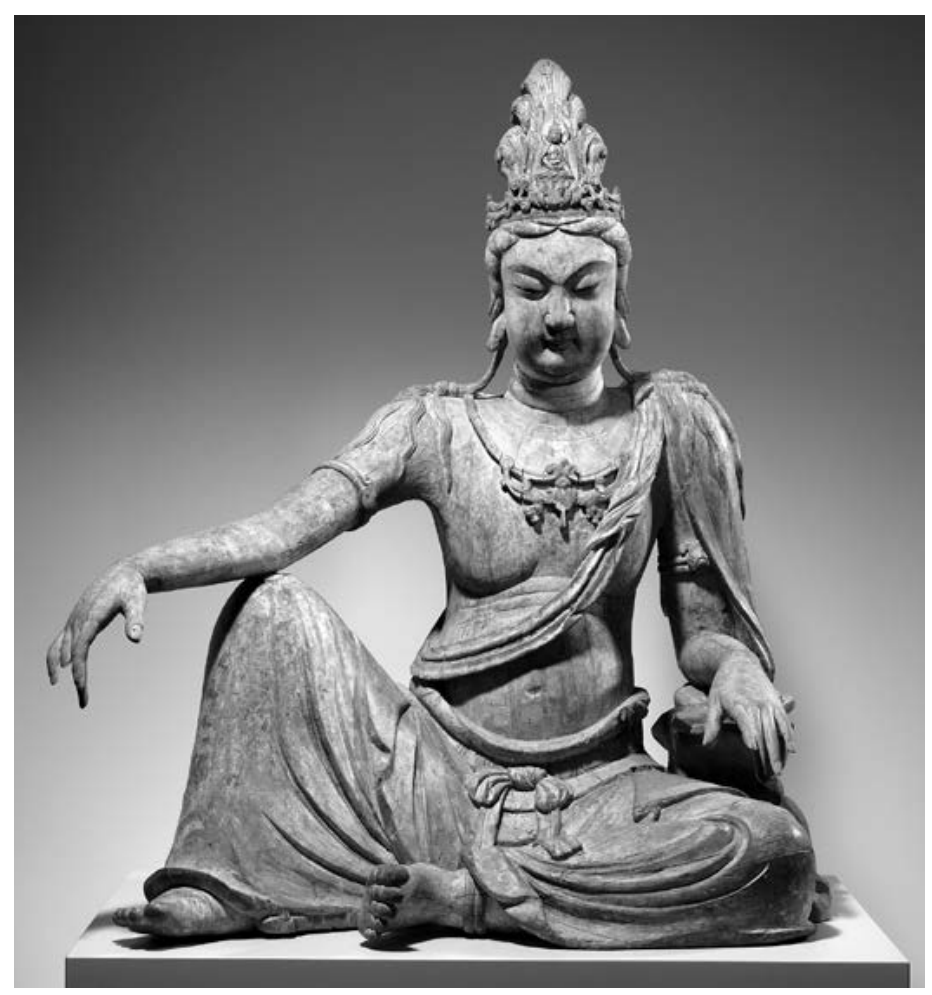

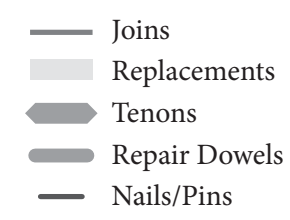

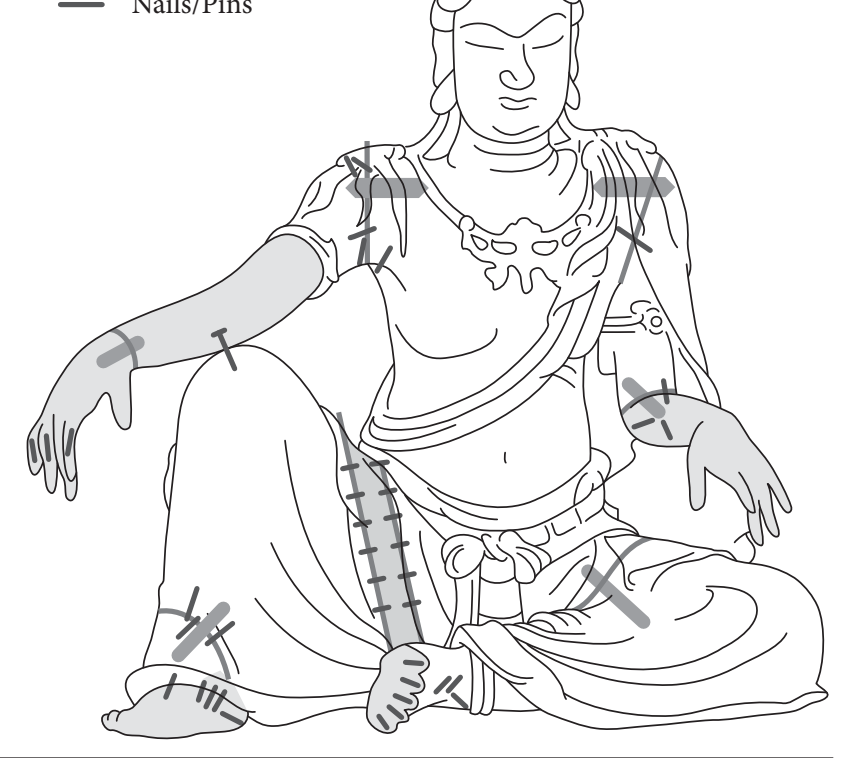

9
8

Bodhisattva Avalokiteśvara in

"Water-Moon" Form. China, 11th century, Liao dynasty (907-1125).

Wood (willow) with traces of pigment, multiple-woodblock construction, $118.1 \times 95.3 \times 71.1$ $\mathrm{cm}$. Metropolitan Museum of Art, Fletcher Fund, 1928 (28.56). Image downloaded from www.metmuseum. org in accordance with the licensefree Open Access for Scholarly Content (OASC) initiative. Work in the public domain

9

Line drawing showing dowel holes, nails, and replacement areas. From Leidy, Denise Patry, and Donna Strahan. Wisdom Embodied: Chinese Buddhist and Daoist Sculpture in The Metropolitan Museum of Art. Copyright (C) 2010 by the Metropolitan Museum of Art, New York. Reprinted by permission in mundane and even secular settings. Consecration rituals may have been tasked with bringing statues to life, but it was only outside of the ritual space that their liveliness was made fully apparent.

Certain medieval Chinese miracle tales observed that the animation of statues was due to their embodiment of the Buddha. One example is the story of a walking wooden sculpture of unknown provenance at Huayansi 華嚴寺 on Mount Xian 峴 山 in Xiangzhou 袈州 (modern-day Henan):

Its face was carved so beautifully that one could never have their fill of gazing at it. In the past, it was supernaturally responsive (zhengying 徵應), but is no longer this way in the present. It is not a Buddha in the full sense. ${ }^{71}$

From this passage, we may conclude that the animation or responsiveness of sculptures was directly associated with their status as sacred icons. The imperative of reading qualities of animation onto sculptures may even have prompted the production of automata, such as the famous fourth-century sandalwood cart that supported a golden Buddha statue surrounded by mechanical Daoist figures that circumambulated the Buddha and performed other oblations. ${ }^{72}$

Nevertheless, while Buddhist sculptures were accorded an extraordinary amount of agency in miracle tales, the textual agency lay ultimately with human devotees. The composition, circulation, and compilation of miracle tales may be considered as performative acts. That is to say, the sculptures came to life in the minds of devotees because they were written into life. Robert Campany has noted the "social networks of narration, estimation, and circulation" that led to the compilation of miracle tales. ${ }^{73}$ These networks therefore can be considered as constituting a participatory practice akin to the painting of the Great Buddha's eyes by the 
gathered assembly at Tôdaiji. In this manner, the eye-opening ceremony and the circulation of miracle tales might be viewed as complementary, rather than competing, practices.

\section{Conclusion}

Statues captured the imagination of medieval Chinese devotees precisely because of their enigmatic nature. Possessing human forms, Buddhist statues straddled the uneasy divide between the sacred and the profane. By endowing statues with life, Buddhist devotees also gave them the human qualities of movement, speech, touch, and the ability to feel pain. In the circulation of miracle tales, Buddhist patrons and devotees, monks and laypeople alike, were able to collectively participate in the "consecration" of statues. The agency of statues as recorded in miracle tales thus rested ultimately upon the agency of devotees.

The animation of statues in Buddhist miracle tales might even be said to have solved epistemological and ontological problems associated with the consecration of Buddhist sculptures. They provided a template for devotees to concretely recognize a true icon by emphasizing the agency of animated statues and their coex-

istence with human devotees. For this reason, medieval Chinese miracle tales of Buddhist sculptures perpetuated the enduring belief that statues had a life of their own, extending far beyond the humans who were responsible for their creation.

Michelle C. Wang, PhD (Harvard, 2008) is assistant professor in the Department of Art and Art History at Georgetown University. She is the author of articles on changing conceptions of mandalas in Tang China, paired images in Buddhist visual culture, and Buddhist art and architecture in East Asia. She is currently completing a book manuscript titled Mandalas in the Making: The Visual Culture of Esoteric Buddhism at Dunhuang. Email: mcw57@georgetown.edu 


\section{NOTES}

AUTHOR'S NOTE:

My appreciation goes to Wei-cheng Lin for his collaboration on the present volume and to Eugene Wang and Paul Copp for their feedback on the conference paper that formed the basis of this essay. I would like to thank the two anonymous reviewers of this article and Mika Natif, Marden Nichols, and Katherine Wasdin for their thoughtful comments and feedback. Jack Chen helpfully responded to queries on medieval Chinese literature, and Donna Strahan kindly shared her expertise on the construction and conservation of medieval Chinese sculptures. I am also grateful to Ren Wei, Geng Yi, and Miki Morita for their assistance regarding image permissions. Finally, sincere thanks to Nancy Micklewright and Zeynep Simavi for overseeing the present volume from beginning to end.

1 For recent scholarly work on visuality and visual culture in Buddhism that counters the "linguistic turn" in Buddhist studies, see Douglas Osto's review of Andy Rotman's Thus Have I Seen: Visualizing Faith in Early Indian Buddhism (Oxford: Oxford University Press, 2009) and Cynthea J. Bogel's With a Single Glance: Buddhist Icon and Early Mikkyō Vision (Seattle: University of Washington Press, 2009) in Art Bulletin 93, no. 4 (2011), 486-89. An important step toward the exploration of sensory culture from the perspective of religious studies is Sally M. Promey, ed., Sensational Religion: Sensory Cultures in Material Practice (New Haven: Yale University Press, 2014). In her introduction to the volume, Promey notes, "A key aspect of the vitality of material is its capacity for transformation, for metamorphosis from one thing to another," an apt description for the consecration of statues. See Sally M. Promey, "Religion, Sensation, and Materi- ality: An Introduction," in Sensational Religion, 14.

2 W. J. T. Mitchell, What Do Pictures Want? The Lives and Loves of Images (Chicago: University of Chicago Press, 2005), 7.

3 Sarah J. Horton, Living Buddhist Statues in Early Medieval and Modern Japan (New York: Palgrave Macmillan, 2007), 11.

4 Donald Swearer, Becoming the Buddha: The Ritual of Image Consecration in Thailand (Princeton and Oxford: Princeton University Press, 2004), 83.

5 Horton, Living Buddhist Statues, 12.

6 Towao Sakaehara, "The Prayers of the Retired Emperor Shomu: Performing Arts and Politics of Todaiji Temple in the 8th Century," Urban Culture Research 1 (2003), 15. I am grateful to Akiko Walley for this reference.

7 Sakaehara, "The Prayers of the Retired Emperor Shomu," 15-22.

8 Michel Strickmann provides a broad cross-cultural perspective on animated icons and consecration ceremonies, stretching back to ancient Egypt and Greece, in the chapter titled "L'Icône Animée" in Michel Strickmann, Mantras et mandarins: le bouddhisme tantrique en Chine, 165-211 (Paris: Éditions Gallimard, 1996). He notes two sources in the Sino-Japanese Buddhist canon that provide instructions for the consecration of icons-one of these is a brief text dated 732 , and the second is a longer text dating circa 1000-but does not provide citations for either text. See Strickmann, Mantras et mandarins, 177-78. According to James Robson, the earliest canonical consecration manual is Foshuo yiqie rulai anxiang sanmei yigui jing 佛說一切如來安 像三昧儀軌經 (T1418, Sūtra Spoken by the Buddha on the Samādhi of all the Tathāgatas for the Proper Installation of Icons), attributed to Dānapāla of the Northern Song. See James Robson, "The 
Buddhist Image Inside-Out: On the Placing of Objects Inside Statues in East Asia," in Tansen Sen, ed., Buddhism Across Asia: Networks of Material, Intellectual, and Cultural Exchange 1 (Singapore: Institute of Southeast Asian Studies, 2014), 295-96. Richard Gombrich states that the earliest reference to an eye-opening ceremony is by Buddhaghosa in the fifth century CE. See Richard Gombrich, "The Consecration of a Buddhist Image," Journal of Asian Studies 26, no. 1 (1966), 26.

9 In addition to the canonical consecration ceremonies described in note 8 , evidence for the practice and knowledge of eye-opening ceremonies in medieval China exists in dedicatory inscriptions that name the donor for the eye-opening ceremony (kaiming zhu 開明主) and master of the vegetarian feast marking the occasion (zhaizhu 斋主). See, for example, the discussion of such dedicatory inscriptions on a Buddhist stele dated 551 in the collection of the Art Institute of Chicago in C. F. K., "A Chinese Buddhist Monument of the Sixth Century A.D.", Bulletin of the Art Institute of Chicago 21, no. 2 (1927), 19-20.

10 In the context of Sinhalese eye-opening ceremonies, Richard Gombrich notes the dangerous nature of vision. When painting in a statue's eyes, the craftsman dares not look directly at the statue, looking into a mirror instead. After he has finished painting in the eyes, the craftsman himself has a "dangerous gaze." He leaves the temple blindfolded and after the blindfold is removed, he destroys the first thing that he sees with a sword. Gombrich, "The Consecration of a Buddhist Image," 24-25.

11 For a list of the thirty-two marks, or lakșana, that identify a great man, see Meher McArthur, Reading Buddhist Art:
An Illustrated Guide to Buddhist Signs and Symbols (London: Thames \& Hudson Ltd., 2002), 95.

12 Swearer, Becoming the Buddha, 15. These sources date to the thirteenth to fourteenth century.

13 Robert H. Sharf, "The Scripture on the Production of Buddha Images," in Religions of China in Practice, ed. Donald S. Lopez Jr. (Princeton, NJ: Princeton University Press), 262. See also Robert DeCaroli, Image Problems: The Origin and Development of the Buddha's Image in Early South Asia (Seattle and London: University of Washington Press, 2015), 153-58.

14 Swearer, Becoming the Buddha, 21.

15 Sharf, "The Scripture on the Production of Buddha Images," 265.

16 Swearer, Becoming the Buddha, 78-79.

17 Swearer, Becoming the Buddha, 79.

18 Peter Stewart, Statues in Roman Society: Representation and Response (Oxford: Oxford University Press, 2003), 261. I am grateful to Marden Nichols for this reference.

19 Donald E. Gjertson, "The Early Chinese Buddhist Miracle Tale," Journal of the American Oriental Society 101, no. 3 (1981), 287.

20 Gjertson, "The Early Chinese Buddhist Miracle Tale," 288-90. For zhiguai literature, see Robert Ford Campany, Strange Writing: Anomaly Accounts in Early Medieval China (Albany: State University of New York Press, 1996), especially $21-33$. For a study of the intersections between medieval Chinese literature and Buddhism, see Kominami Ichirō 小南一郎, “Rikuchō Zui Tō shōsetsushi no tenkai to Bukkyō shinkō" 六朝隋唐小说史の展开と佛教信仰 (The History of the Development of Six Dynasties, Sui, and Tang Fiction and Buddhist Faith) in Chūgoku chūsei no shūkyō to bunka 中国中世の宗教と文化, ed. Fukunaga Mitsuji 福永光司 (Medieval Chinese Religion and Culture), (Kyoto: Kyoto Daigaku Jinbun kagaku kenkyūsho, 1982), 415-500.

21 Gjertson, "The Early Chinese Buddhist Miracle Tale," 287.

22 S.F. Teiser, “T’ang Buddhist Encyclopedias: An Introduction to Fa-yüan chu-lin and Chu-ching yao-chi," T'ang Studies 3 (1985), 120-21. For the "profoundly lay" orientation of miracle tales, see Robert Ford Campany, Signs from the Unseen Realm: Buddhist Miracle Tales from Early Medieval China (Honolulu: University of Hawai'i Press, 2012), 31. Li Xiyun hypothesizes on the role played by monks in the dissemination of miracle tales; see Li Xiyun 李希运, “Lun Wei Jin Nanbeichao Fojiao zhiguaide chuanbu” 论魏 晋南北朝佛教志怪的传布 (Thoughts on the Dissemination of Buddhist anomaly tales of the Wei, Jin, and Northern and Southern Dynasties), Zibo xueyuan xuebao 淄博学院学报 51 (1999.2), 74-75.

23 For studies of this text, see Koichi Shinohara, "A Source Record of the Ruijing lu ('Records of Miraculous Scriptures')," Journal of the International Association of Buddhist Studies 14, no. 1 (1991), 73-154; Koichi Shinohara, "Ji shen-zhou san-bao Gan-tong-lu: Some Explanatory Notes," in Kalyāna-mitta: Professor Hajime Nakamura Felicitation Volume, ed. V. N. Jha, 203-24 (Delhi: Sri Satguru Publications, 1991); and Koichi Shinohara, "Changing Roles for Miraculous Images in Medieval Chinese Buddhism: A Study of the Miracle Image Section in Daoxuan's 'Collected Records," in Images, Miracles, and Authority in Asian Religious Traditions, ed. Richard H. Davis, 141-88 (Boulder, CO: Westview Press, 1998). In the last article, Shinohara focuses exclusively on miracle tales of 
Buddhist sculptures, particularly "royal images." He also provides an exhaustive list of each of the fifty image stories, cross-referencing them against other primary and secondary textual sources; see Shinohara, "Changing Roles for Miraculous Images in Medieval Chinese Buddhism," 176-88.

24 Robert H. Sharf, Coming to Terms with Chinese Buddhism: A Reading of the Treasure Store Treatise (Honolulu: University of Hawai'i Press, 2002), 83.

25 For omens in pre-Buddhist art, see Wu Hung, The Wu Liang Shrine: The Ideology of Early Chinese Pictorial Art (Stanford: Stanford University Press, 1989), 73-107, 234-44. Alexander Soper noted the ability of statues to portend future events, particularly regarding political crises; see Alexander Coburn Soper, Literary Evidence for Early Buddhist Art in China, Artibus Asiae Supplementum 19 (Ascona: Artibus Asiae Publishers, 1959), 245-50. He further argues that it is unlikely that miracle tales regarding animated sculptures were an indigenous Chinese phenomenon due to the relative inexperience of the Chinese with the cult of images; see Soper, Literary Evidence, 243-44.

26 Campany, Signs from the Unseen Realm, 31-32. The emphasis on ganying and its pre-Buddhist origins counters Soper's assertion that miracle tales involving animated statues were unlikely to have been invented by the Chinese themselves. See Soper, Literary Evidence, 243-44.

27 Sharf, Coming to Terms with Chinese Buddhism, 77-78. See also Campany, Signs from the Unseen Realm, 37, in which he argues that miracle tales both effected and reflected certain aspects of sinicization.

28 Gjertson, "The Early Chinese Buddhist Miracle Tale," 291. For a brief discussion of karmic response and auspicious signs in the context of Avalokiteśvara statues and Buddha relics, see Li Jianguo 李剑国, Tangqian zhiguai xiaoshuo shi 唐前志怪小 说史 (A History of Pre-Tang Anomaly Tales) (Tianjin: Nankai daxue chubanshe, 1984), 415-16, 436-37. For miracle tales pertaining to Avalokiteśvara, see Sano Seiko 佐野诚子, “Ō En Meishoki to Riku Kō Kei Kanzeon ōkenki” 王琰“冥祥记” と 陆杲‘繫观世音应验记’'(Wang Yan's Record of Signs from the Unseen Realm and $\mathrm{Lu}$ Gao's Record of Miracle Tales Related to Guanyin), Wakō Daigaku hyōgen gakubu 和光大学表现学部 10 (2009), 1-11.

29 Campany, Signs from the Unseen Realm, 12, 63-67.

30 Campany, Signs from the Unseen Realm, 65-66. As Campany notes, the "marks" referred to in this passage may refer simultaneously to the practice of physiognomy and the lakșana, or marks of a great man who characterized the body of Śākyamuni Buddha. See Campany, Signs from the Unseen Realm, 65 , note 19.

31 Fayuan zhulin, T2122:406b21-28. My translation is adapted from Soper, Literary Evidence, 42-43.

32 Or, as Deborah Tarn Steiner asks of ancient Greek statues, "What precise links might exist between the container and the contained? Does the surface of the statue stand in tension with the imperceptible contents within, or can it actually exhibit the indwelling force through its visible appearance?" See Deborah Tarn Steiner, Images in Mind: Statues in Archaeic and Classical Greek Literature and Thought (Princeton and Oxford: Princeton University Press, 2001), 79.

33 Campany, Signs from the Unseen Realm, 66.

34 Glen Dudbridge, "Buddhist Images in Action: Five Tales from the Tang," Cahiers d'Extrême-Asie 10 (1998), 381. I am grateful to Paul Copp for this reference. For a more comprehensive treatment of this work, see Glen Dudbridge, Religious Experience and Lay Society in Tang China (Cambridge: Cambridge University Press, 1995).

35 Dudbridge raises these questions in "Buddhist Images in Action," 384-85.

36 Dudbridge, "Buddhist Images in Action," 385-87. It should be noted that Dudbridge views miracle tales as representative of lay devotion, stating that animated sculptures "have no need to wait for trained, qualified and initiated priests to perform elaborate ties inspiring them with life: they burst out by their own power all unpolished from the flames, driven by strong social obligations to support their generous sponsor." While I am in general agreement with Dudbridge on most points, I do not view miracle tales as adhering to a strictly lay point of view, as I discuss in this essay.

37 Dudbridge, "Buddhist Images in Action," 385.

38 Dudbridge points out the unfinished state of the statues; see Dudbridge, "Buddhist Images in Action," 386. Dudbridge's position contradicts the emphasis that Michel Strickmann placed on ritual manuals and consecration ceremonies as the main forces behind the animation of Buddhist sculptures. See also Dudbridge, "Buddhist Images in Action," 379.

39 A comparative perspective on Greek statuary is provided in Steiner, Images in Mind, 114-15.

40 Dudbridge, "Buddhist Images in Action," 386. A similar tale of unconsecrated yet animated statues in a mortuary context is discussed in Jeehee Hong, "Virtual Theater of the Dead: Actor Figurines and Their Stage in Houma Tomb No. 1, Shanxi Province," Artibus Asiae 71, no. 1 (2011), 82-83. 
41 Although I do not analyze them at length in this article, it should be noted that there was a well-established tradition of ruixiang 瑞像, or auspicious images that flew to China from the western regions. Narratives regarding ruixiang were recorded in miracle tales and in mural and portable paintings from the Mogao cave shrines at Dunhuang. See Wu Hung, "Rethinking Liu Sahe: The Creation of a Buddhist Saint and the Invention of a 'Miraculous Image', Orientations 27, no. 10 (1996), 32-43, and Roderick Whitfield, "Ruixiang at Dunhuang," in Function and Meaning in Buddhist Art, ed. K. R. Kooij and H. van der Veere, (Groningen: Egbert Forsten, 1995), 149-56.

42 Luoyang jielan ji, T2092:1003c13-1004a1. My translation is adapted from Soper, Literary Evidence, 8. See also Fozu tongji 佛祖統紀 (Complete Chronicle of the Buddha and Patriarchs), compiled in 1269 by Zhipan 志磐 (1220-1275) for a similar account of the same tale (T2035:355b27-c2).

43 This statue was completed in the year 375. See Soper, Literary Evidence, 15-16. Elements of the tale appear in several other texts: Gaoseng zhuan 高僧傳 (T2059, Biographies of Eminent Monks), Jishenzhou sanbao gantonglu 集神州三寶 感通錄 (T2106, Record of the Miraculous Responses of the Three Treasures in China), and Bianzhenglun 讋正論 (T2110, Discerning the Correct). For this statue, see also Marylin Martin Rhie, Early Buddhist Art of China and Central Asia 2: Text, (Leiden and Boston: Brill, 2002), 83-85.

44 Gaoseng zhuan, T2059:352b11-12. My translation is adapted from Soper, Literary Evidence, 15. Soper also notes that Wan Shan is located ten $l i$ northwest of Tanxi Monastery.
45 Ji shenzhou sanbao gantonglu, T2106:414c24-27. See Soper, Literary Evidence, 16.

46 Bianzhenglun, T2110:505a13. See Soper, Literary Evidence, 16.

47 See, for example, the procession on the Buddha's birthday from the Changqiu Temple in Luoyang, as described in W. J. F. Jenner, Memories of Loyang: Yang Hsüan-shih and the Lost Capital (493534) (Oxford: Clarendon Press; New York: Oxford University Press, 1981), 165.

48 Luoyang jielan ji, T2092:101721-18a2. See Soper, Literary Evidence, 111.

49 Luoyang jielan ji, T2092:1018a8-13. My translation is adapted from Soper, Literary Evidence, 111.

50 Ji shenzhou sanbao gantonglu, T2106:415c22-23. My translation is adapted from Soper, Literary Evidence, 24-25. Soper discusses the political background of Baorong's rebellion on $\mathrm{p}$. 25 . The walking statue is presented as an omen of Baorong's failure and the return of authority to the Liang ruler.

51 Ji shenzhou sanbao gantonglu, T2106:415c23-26. My translation is adapted from Soper, Literary Evidence, 25.

52 A dramatic example of this from popular culture is the weeping angels of the $D r$. Who episode "Blink" (aired June 9, 2007). They moved only when unseen, forcing Sally Sparrow and other characters to keep their eyes on them at all times.

53 Ji shenzhou sanbao gantonglu, T2106:418a4-9). My translation is adapted from Soper, Literary Evidence, 92.

54 Bernard Faure makes a similar observation regarding the "valorized stillness" of Buddhist icons in Bernard Faure, "The Buddhist Icon and the Modern Gaze," Critical Inquiry 24, no. 3 (1998), 770.

55 A comparative perspective concerning Greek statues is provided in Steiner, Images in Mind, 136. Steiner proceeds to describe instances in which the lifelessness of statues is thrown into sharper focus on account of their inability to walk, hear, or speak. See Steiner, Images in Mind, 140-41.

56 Fayuan zhulin, T2122:389b24-c7. My translation is adapted from Soper, Literary Evidence, 64-65. A similar tale of Sun Hao 孙皓 breaking out in boils after bathing a golden image in excrement is discussed in Soper, Literary Evidence, 6, and presented as evidence of the efficaciousness of Buddhist statues by Zhang Qingmin 张庆 民, Wei Jin Nanbeichao zhiguai xiaoshuo tonglun 魏晋南北朝志怪小说通论 (A General Survey of Anomaly Tales from the Wei, Jin, and Northern and Southern Dynasties) (Beijing: Shoudu shifan daxue chubanshe, 2000), 258.

57 For a similar tale, see Campany, Signs from the Unseen Realm, 238.

58 Ji shenzhou sanbao gantonglu, T2106:418c22-27. My translation is adapted from Soper, Literary Evidence, 58-59.

59 Ji shenzhou sanbao gantonglu, T2106:415c1-2. My translation is adapted from Soper, Literary Evidence, 24.

60 Ji shenzhou sanbao gantonglu, T2106:416b27-c5.

61 Ji shenzhou sanbao gantonglu, T2106:420b27-c2. My translation is adapted from Soper, Literary Evidence, 115.

62 Steiner, Images in Mind, 91-95.

63 Campany, Signs from the Unseen Realm, 56-57.

64 The clay would be removed after the layers of lacquer had dried, producing a hollow-core, dry-lacquer sculpture. A Sui dynasty dry-lacquer sculpture in the Walters Art Museum, the oldest known Chinese example, was produced on a wooden support, and some clay was used in order to produce volumetric details. 
See Donna Strahan, "The Walters Chinese Wood-and-Lacquer Buddha: A Technical Study," The Journal of the Walters Art Gallery 51 (1993), 105-20.

65 George L. Hersey, Falling in Love with Statues: Artificial Humans from Pygmalion to the Present (Chicago: University of Chicago Press, 2006), 69. Here, Hersey cites Aristotle, De Partibus, 724, and the latter's concept of the liquid quality of lifeforms, similar to the properties of molten metals.

66 For the textile organs placed inside the late tenth-century Seiryōji 清凉寺 Shaka, which was taken to Japan from China by the monk Chōnen 奝然 (938-1016), see Helmut Brinker, Secrets of the Sacred: Empowering Buddhist Images in Clear, in Code, and in Cache (Lawrence, KS, and Seattle: Spencer Museum of Art, University of Kansas and University of Washington Press, 2011), 41. Brinker speculated that such a practice may have been more widespread in medieval East Asian sculpture than is currently recognized; Brinker, Secrets of the Sacred, 42. On the other hand, James Robson notes that the earliest statues with textile organs seem to date to the Northern Song, questioning whether the lack of similar organs in earlier sculptures is due to the vulnerability of the materials involved. See Robson, "The Buddhist Image Inside-Out," 296-98.

67 Donna K. Strahan, "Creating Sacred Images of the Buddha: A Technical Perspective," in Denise Patry Leidy and Donna Strahan, Wisdom Embodied: Chinese Buddhist and Daoist Sculpture in the Metropolitan Museum of Art (New York: Metropolitan Museum of Art, 2010), 33-34.

68 Leidy and Strahan, Wisdom Embodied, 75-78.

69 Strahan, "Creating Sacred Images of the Buddha," 36-37.

70 Leidy and Strahan, Wisdom Embodied, 116-19.

71 Ji shenzhou sanbao gantonglu, T2106:420c23-24. My translation is adapted from Soper, Literary Evidence, 115-16.

72 Joseph Needham, Science and Civilisation in China, Vol. 4: Physics and Physical Technology, Part 2: Mechanical Engineering (Cambridge: Cambridge University Press, 1965), 159-60.

73 Campany, Signs from the Unseen Realm, xii. 